\title{
LOGARITHMISCHE RECHENTAPELN
}

\section{FÜR CHEMIKER, \\ PHARMAZEUTEN, MEDIZINER UND PHYSIKER.}

\section{Im Einverstăndnis mit der}

Atomgewichtskommission der Deutschen Chemischen Gesellschaft für den Gebrauch im Unterrichtslaboratorium und in der Praxis berechnet und mit Erlăuterungen versehen

ron

Professor Dr. F. W. Küster.

Achte Auflage.

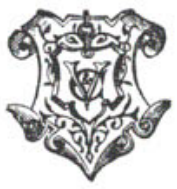

Leipzig

Verlag von Veit \& Comp. 1908 